\title{
Late Pleistocene-Holocene vegetation and climate change in Ebinur Betula wetland, Xinjiang, NW China
}

\author{
${ }^{1}$ State Key Laboratory of Vegetation and Environmental Change, Institute of Botany, Chinese Academy of Sciences, Beijing 100093, China; \\ *Corresponding author, E-mail: zhangygl@ibcas.ac.cn \\ ${ }^{2}$ School of Geography and Sustainable Development, University of St Andrews, Scotland KY16 9AL, UK
}

(Received: April 22, 2020; Revised accepted: September 12, 2020)

https://doi.org/10.18814/epiiugs/2020/020085

Late Pleistocene-Holocene has been regarded as one of the most important periods in the history of climate change. The specific objectives of this study were to restore vegetation change and climatic evolution in the Ebinur Betula wetland of Xinjiang in China over the past 16,000 years based on 15 surface and 70 fossil pollen data. Research results revealed that a relatively humid climate existed from 12,230 to 9,260 cal. aBP, followed by a reducing humidity period between 9,260 cal. aBP and 3,303 cal. aBP. After 3,303 cal. aBP, the aridity increased further, especially in the last 600 years. Additionally, three high peaks of the Betula pollen in this wetland occurred at the end of the Last Glacial Maximum, at the beginning of early Holocene and during the Medieval Warm Period, all of which pointed to the amelioration of climatic conditions. However, the percentage of Betula has also been on a declining trend in the past 600 years, indicating a drying climate and intensified human activities. Therefore, these findings are conducive to exploring the impacts on wetland vegetation caused by climate change and anthropogenic disturbance in different periods, and providing the reference frame for wetland restoration and ecological construction in China.

\section{Introduction}

Wetlands have gained much attention for studying past global environment changes, given their extreme sensitivity to climate change (Aryal et al., 2019; Oo et al., 2019; Solangi et al., 2019). Many researchers have utilized pollen (Wang et al., 2013), charcoal (Zhang et al., 2015), phytoliths (Ledru et al., 2013) and other environmental proxies in order to reconstruct the paleovegetation and paleoclimate of wetlands in semi-arid and arid areas. As the largest saltwater lake in Xinjiang in arid and semi-arid regions of Northwest China, the Ebinur Lake has attracted scientists in research in this field of research for many years. Earlier studies conducted at the Ebinur Lake were based on ZK00B core (Li, 1993) and AZ Profile (Jiang and Wu, 2003). Despite their long-time scales dating back to nearly $20,000 \mathrm{cal}$. aBP, the relatively low resolution of sediment samples caused loss of considerable details in the climate changes. Recent studies have focused on the environment evolution during Late Holocene with improved time resolution, such as Ash core (Miao et al., 2003; Yan et al., 2003) and AB01 core (Ma et al., 2011). These studies were mostly based on the lacustrine sediments from the western and the middle of Ebinur lake, rather than on the typical wetland (marsh) deposits from the eastern side. The Ebinur birch wetland is a small freshwater wetland that lies eastern of Ebinur Lake, which is dominated by Betula microphylla and typical aquatic plants including Thelypteris palustris and Phragmites, which has different environment from other parts of Ebinur Lake. How about the response of wetland vegetation to climate change and its evolutive process in this Betula wetland? What effect did climate change have on birch pollen in the study area?

The last 16,000 years have been regarded as one of the most important periods in the history of climate change, during which a large number of climatic fluctuations have occurred, including the Holocene Megathermal and Medieval Warm Period (MWP) (Hughes and Diaz, 1994). Considerable evidence has been obtained from various environmental records to support the existence of the Holocene Megathermal and MWP (Guiot, 2012; Viau et al., 2012). However, controversy about humidity and dryness conditions in northern Xinjiang during these periods still exists (Miao et al., 2003; Yan et al., 2003; Zhang et al., 2009). This study seeks to address these questions by performing pollen analysis and Detrended correspondence analysis (DCA) at the Ebinur Betula wetland to infer climatic and vegetation conditions during the last 16,000 years. The main issues addressed in this paper are: Materials and Methods, Results, Discussions and Conclusions. The methodology flowchart is shown in Fig. 1.

\section{Materials and Methods}

\section{Regional Setting}

Ebinur Lake extends from $44^{\circ} 30^{\prime} \mathrm{N}$ to $45^{\circ} 09^{\prime} \mathrm{N}$ and from $82^{\circ} 36^{\prime} \mathrm{E}$ to $83^{\circ} 50^{\prime} \mathrm{E}$, southwest of Junggar Basin, Xinjiang, China. It is the largest Salt Lake as well as the lowest point in North of Xinjiang, with the elevation of $189 \mathrm{~m}$. Although dominated by the Gobi Desert land- 


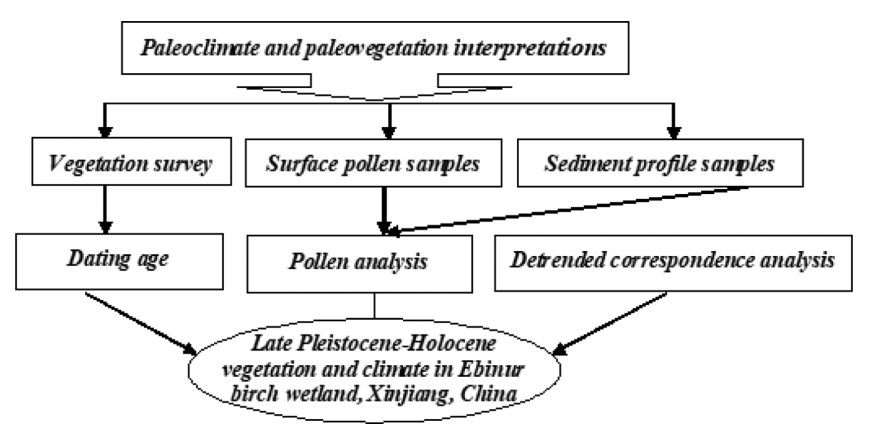

Figure 1. The methodology flowchart of this study.

scape, varied landscape types are well developed by virtue of the Ebinur Lake such as rock desert, gravel desert and marshes (Chen et al., 2006). The area has a temperate continental arid climate, with far more evaporation than precipitation. The mean annual temperature is $7.8{ }^{\circ} \mathrm{C}$ and the mean annual precipitation is $95 \mathrm{~mm}$. Winds from the Alataw Pass result in gales stronger than $17 \mathrm{~m} / \mathrm{s}$ for $165 \mathrm{~d}$ every year in Ebinur Lake.

Our study area has the typical birch marsh, which is located at the Southeast side of Ebinur Lake. Field survey shows Amaranthaceae dominates the vegetation in our study area, with $90 \%$ of vegetation coverage. Betula microphylla (Betulaceae) and typical aquatic plants including Thelypteris palustris (Thelypteridaceae) and Phragmites grow there. Besides, there also exists Glycyrrhiza (Leguminosae), Zygophyllum fabago (Zygophyllaceae), and Cynanchum auriculatum (Apocynaceae). Betula microphylla is a valuable natural tree species and Germplasm Resources in Northern Xinjiang of China. But at present, it is in an endangered state. Only a small amount of this species still exists in the area, with a total number of less than 500 (Zhang et al., 2019).

\section{Vegetation Survey and the Collection of Surface Pollen Samples}

Fifteen surface pollen samples (Fig. 2), chiefly consisting of litter, moss pollsters and topsoil, were obtained from marsh area in Ebinur Wetland Nature Reserve to study the relationship between pollen and modern vegetation (Fig. 3). At each sample site, we conducted the vegetation quadrat survey and recorded the latitude, longitude and elevation information using a global positioning system (GPS) handset.

\section{Sediment Profile Samples}

To fulfil the purpose of reconstructing the paleovegetation and past climate in Ebinur birch wetland, a 140-cm-deep (profile III: 44 $34^{\prime} 11.7^{\prime \prime} \mathrm{N}$,

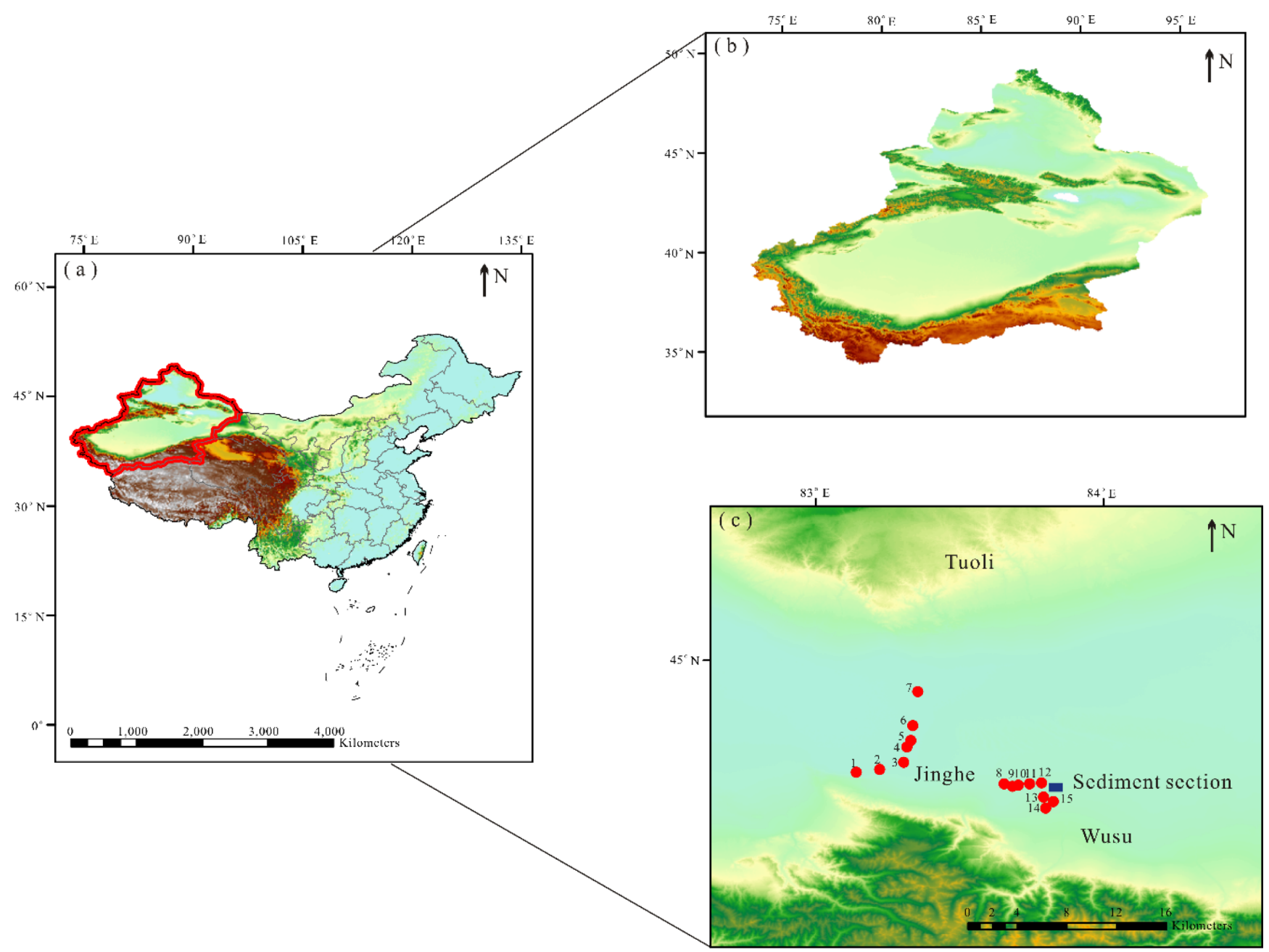

Figure 2. Digital Elevation Model diagram of China (a), Xinjiang (b) and sampling points (c) in Ebinur Betula Wetland, northern Xinjiang, China. 


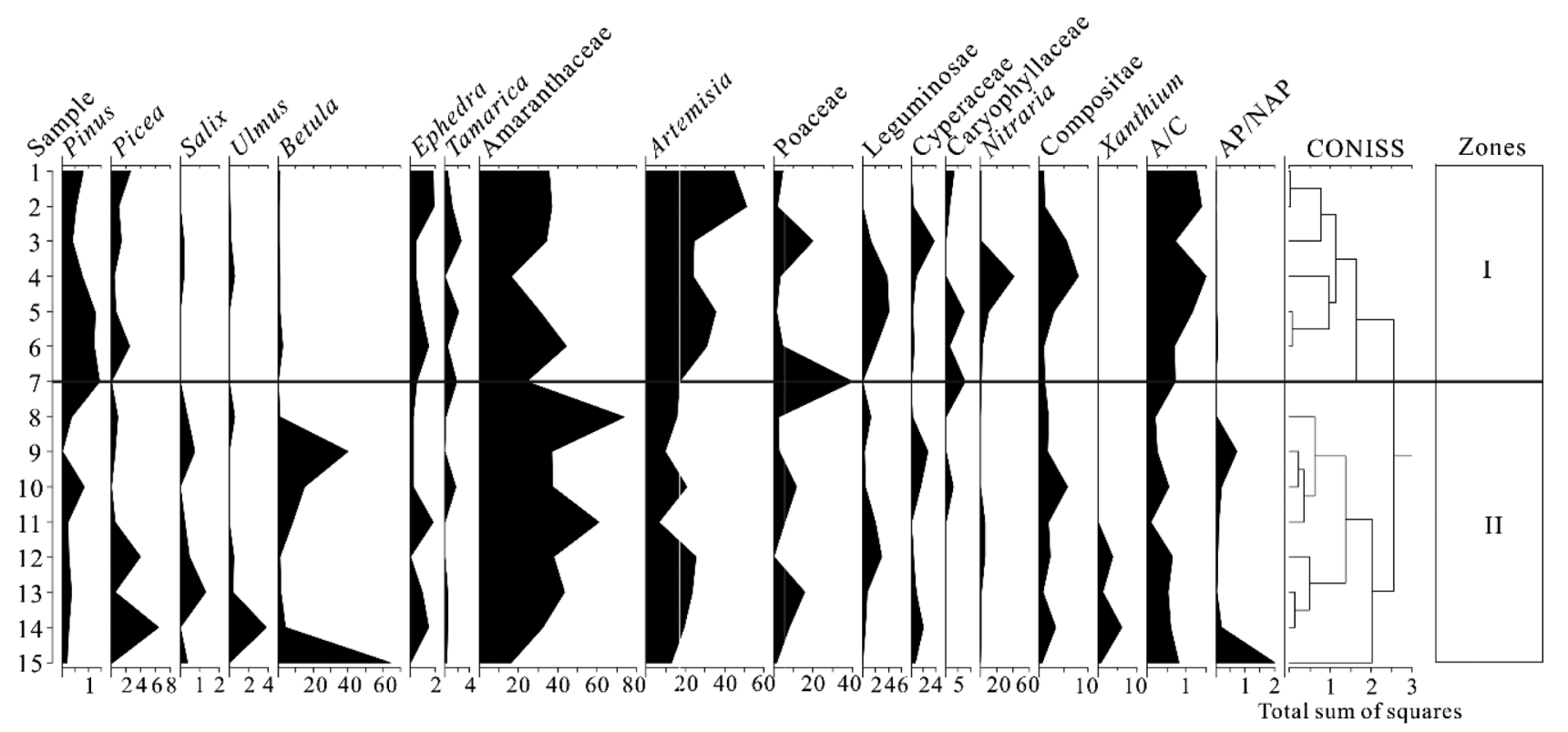

Figure 3. Surface pollen percentages of Ebinur Betula wetland, northern Xinjiang, China.

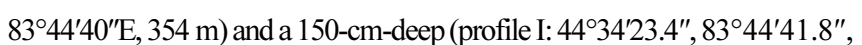
$356 \mathrm{~m}$ ) manual excavated sediment profiles belonging to marsh deposits were obtained from Birch Conservation station of Ebinur Wetland in 2010 (Fig. 2). Here, we present analytical results obtained from the 140-cm-long profile III. We took 70 samples from the freshly excavated sediment for pollen analysis at $2 \mathrm{~cm}$ intervals. Additionally, two subsamples taken from the depths of $10-15 \mathrm{~cm}$ and $60-65 \mathrm{~cm}$ were sent for Accelerator Mass Spectrometry (AMS) ${ }^{14} \mathrm{C}$ dating. Five samples for Optically Stimulated Luminescence (OSL) taken from profile I in the Ebinur birch wetland at the depths of $30 \mathrm{~cm}, 60 \mathrm{~cm}, 90 \mathrm{~cm}, 120 \mathrm{~cm}$, and $150 \mathrm{~cm}$ were performed using an automated Daybreak 2200 OSL reader system. All dates were calibrated to calendar years before present $(\mathrm{BP}=\mathrm{AD} 1950)$ and used to establish the age-depth models using the open-source software Bacon (Fig. 4).

\section{Pollen Analysis}

We treated all surface and sediment pollen samples weighing $30 \mathrm{~g}$ with $10 \%$ hydrochloric acid $(\mathrm{HCl}), 10 \%$ Sodium hydroxide $(\mathrm{NaOH})$, heavy liquid and acetolysis prior to mounting the pollen residues on slides. Each sample was examined under the Olympus microscope at $40 \times 10$ magnifications at a minimum of 100 grains. And then pollen percentages were calculated based on the total sum of all counted pollen and fern spores. Pollen concentration (grains/g) was calculated using the method described in Davis (1965). The pollen diagram was drawn using Tilia software (Grimm, 1990) and pollen assemblage zones were divided by method of cluster analysis using CONISS (Fig. 3 and 5).
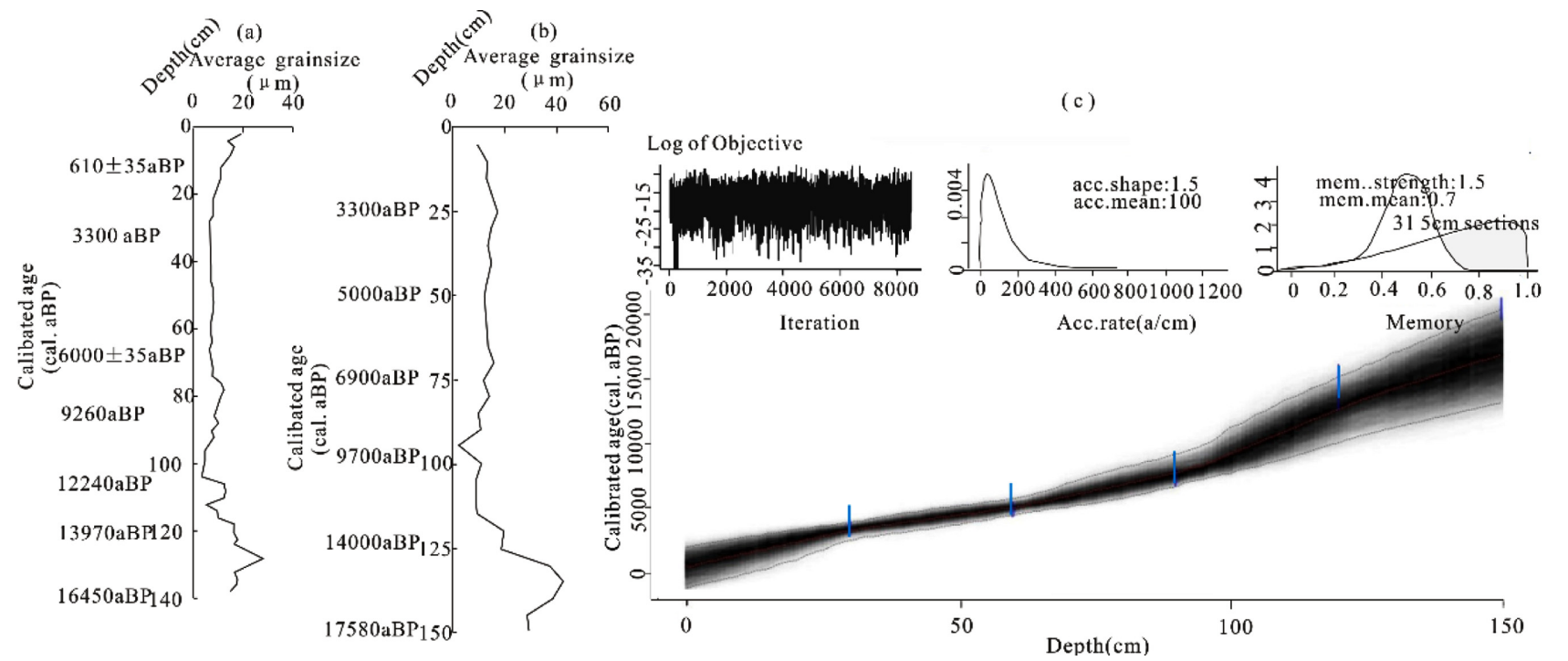

Figure 4. Average grain size and Age-depth model of profile I and profile III of Ebinur Betula wetland, northern Xinjiang, China. (a) Average grain size of profile III, (b) Average grain size of profile I, (c) Age-depth model of profile I. 


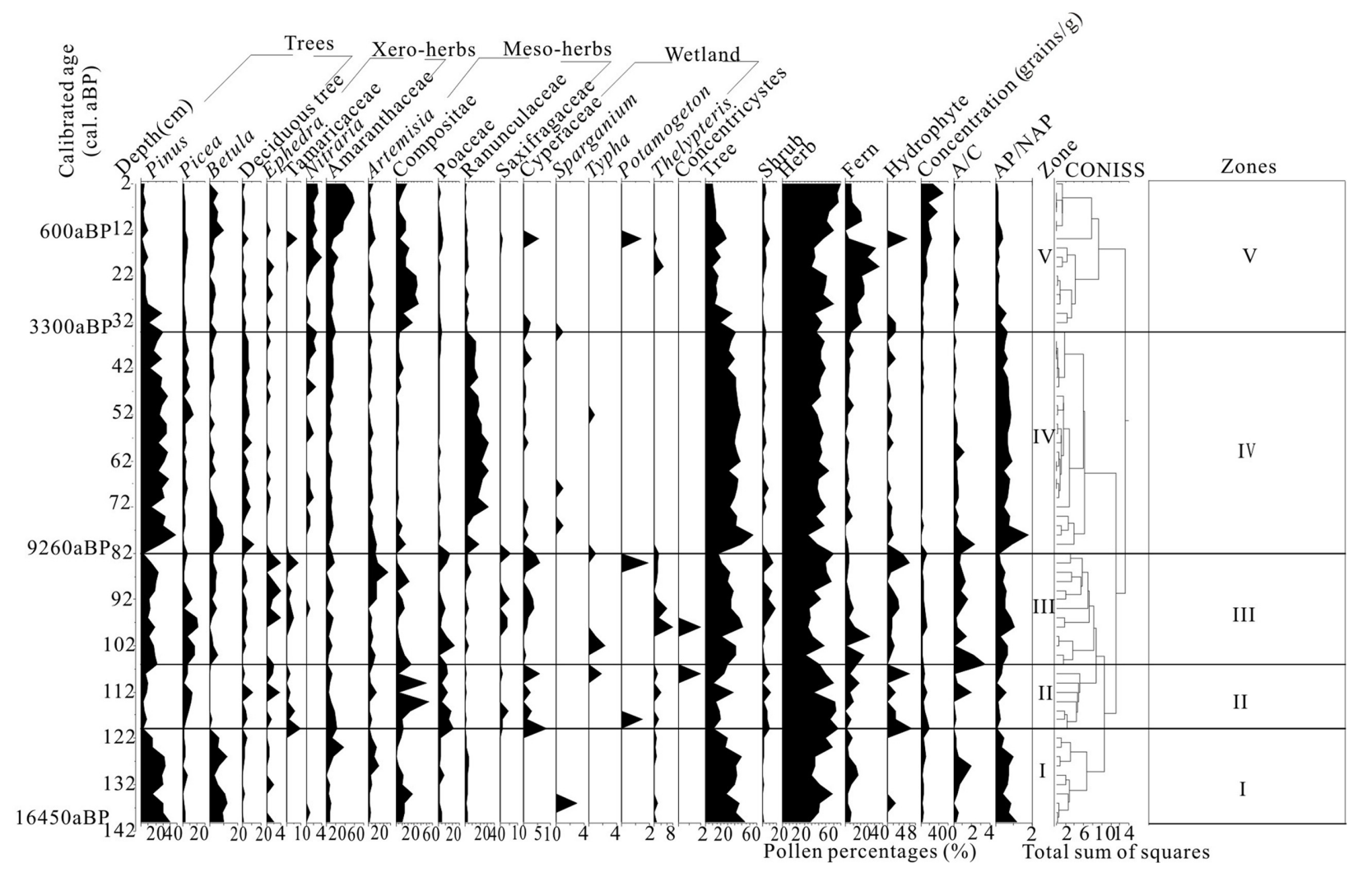

Figure 5. Fossil pollen assemblages of profile III of Ebinur Betula wetland, northern Xinjiang, China.

\section{Data Treatment and Statistical Analyses}

DCA has been widely used to examine the relationship between surface pollen assemblages and modern vegetation, providing reference information for reconstructing paleovegetation and paleoclimate by interpreting fossil pollen data (Zhang et al., 2010; Zhang et al., 2017). We chose typical pollen taxa in this area such as Pinus, Picea, Betula, Ephedra, Amaranthaceae, Artemisia, Poaceae, Cyperaceae, Nitraria and Compositae to perform DCA analysis using Canoco 4.5 (Ter Braak and Smilauer 2002) (Fig. 6).

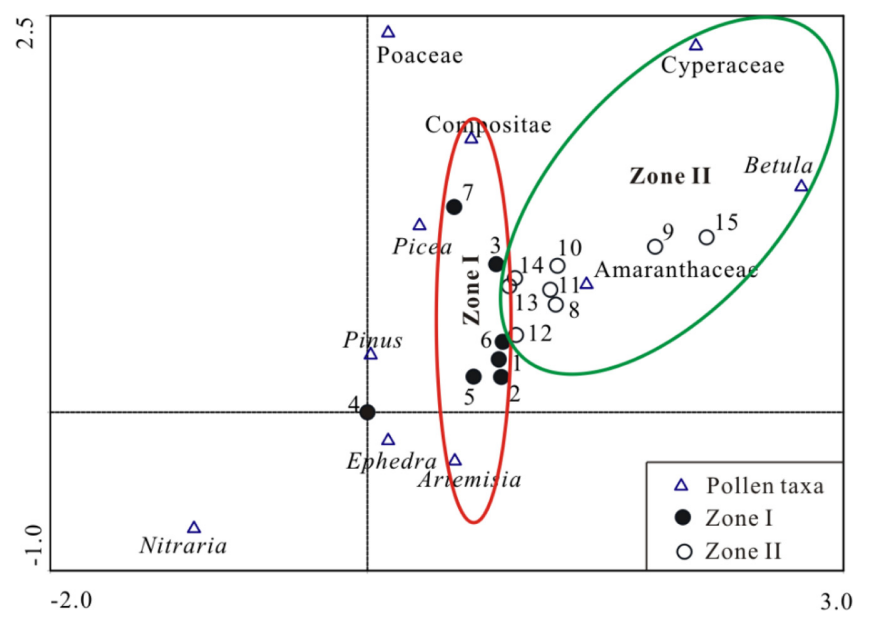

Figure 6. Detrended correspondence analysis of surface pollen data of profile III in Ebinur Betula wetland, northern Xinjiang.

\section{Results}

\section{Modern Pollen Spectra}

Based on the characteristics of surface pollen and modern vegetation observational data, the surface pollen spectra can be categorized into two pollen assemblage zones (Fig. 3), as follows.

Zone I (at the elevation of 200-250m) includes 7 samples, with the dominant species of Salsola collina, Kalidium foliatum, Haloxylon ammodendron and Petrosimonia sibirica. Pollen assemblages mainly consist of Amaranthaceae, Artemisia and other xerophytic desert vegetation types. The mean percentage of arboreal pollen is only $3.3 \%$, including Picea (mean 1.2\%) and Betula (mean 0.9\%). Additionally, this zone shows the ratio of Artemisia to Amaranthaceae ( $\mathrm{Ar} / \mathrm{Am}$ ) is 1.1.

Zone II (at the elevation of $350-400 \mathrm{~m}$ ) is composed of 8 samples, whose dominant species are Chenopodium serotinum, Carex arcatica and the endangered species Ebinur birch (Betula microphylla). Herb pollen (such as Amaranthaceae, Artemisia, Poaceae) still dominates in the pollen assemblages, reaching to $71.8 \%$. However, arboreal pollen percentage significantly increases with the average and peak value rising to $19.9 \%$ and $65.1 \%$, respectively. Betula and other deciduous arboreal pollen (such as Ulmus and Salix) reach their peak values in this zone, especially for Betula, whose maximum value is high up to $64.3 \%$. Ar/Am ratio is lower than that in Zone I.

\section{Age}

Two ${ }^{14} \mathrm{C}$ dates were calibrated with the results of $610 \pm 35 \mathrm{aBP}(621$ - 
649 cal. aBP $)$ and $6,000 \pm 35 \mathrm{aBP}(6,792-6,885$ cal. aBP $)$, respectively for profile III. We defined the corresponding age of uppermost part as $0 \mathrm{aBP}$ and calculated the ages of remaining samples on the assumption that the rate of sediment accumulation stayed constant between those mentioned calibrated ages. Therefore, the age of the bottom of the profile can be extrapolated to $16,450 \mathrm{cal}$. aBP. Calibrated radiocarbon ages are used throughout this paper.

The age of the bottom of profile I can be extrapolated to $17,580 \mathrm{cal}$. $\mathrm{aBP}$, which is similar to the result of profile III. Fig. 3 shows that these two profiles had similar depth, grain size and calculated ages, suggesting that the calculated and calibrated age result of profile III is credible.

\section{Fossil Pollen Spectra}

Among all the identified pollen types, there were 19 arboreal taxa, 10 shrub taxa, 36 herbaceous taxa, 7 fern taxa in the 70 fossil pollen samples, giving a total of 72 palynomorph types. According to the characteristics and the result of cluster analysis, we divided the pollen diagram into five pollen assemblage zones (Fig. 5), which can be described as follows.

Zone I (140-120 cm; 16,450-13,970 cal. aBP) is dominated by herb and arboreal pollen $(51.74 \%$ and $40.05 \%)$. Dominant herb pollen types are Compositae (14.15\%) and Amaranthaceae (10.79\%). Dominant arboreal pollen types are Pinus $(27.14 \%)$, Betula (8.12\%) and Picea $(2.83 \%)$. The percentages of fern spores are relatively low with an average of $7.07 \%$. Additionally, as an emergent aquatic pollen, Sparganium is recorded at the depth of $136 \mathrm{~cm}$, occupying $2.97 \%$. The Ar/Am has the maximum value of 2 .

Zone II (120-106 cm; 13,970-12,230 cal. aBP) is marked by the significant decrease in arboreal pollen and sudden occurrence of wetland pollen types and algal palynomorphs. The percentages of Pinus and Betula drop to $6.22 \%$ and $0.21 \%$, respectively; whereas Picea rises modestly to $6.81 \%$. Typha $(1.75 \%)$ and Concentricystes can be found occasionally at the depth of $108 \mathrm{~cm}$; Potamogeton (1.48\%) appears at the depth of $118 \mathrm{~cm}$. Moreover, Cyperaceae is at its highest level in the whole record with the mean percentage of $3.11 \%$.

Zone III (106-82 cm; 12,230-9,260 cal. aBP) reveals dominance of herb (mean $48.44 \%$ ) and arboreal (mean $35.12 \%$ ) pollen. When compared with zone II, Pinus (16.82\%), Picea (9.59\%), Betula (2.72\%) and other deciduous and broad-leaved arboreal pollen increase in different degrees, but the lowest mean value of herb pollen is recorded. Wetland pollen is still dominated by Cyperaceae, Typha and Potamogeton. Significantly, Concentricystes occurs at the depth of $98 \mathrm{~cm}$. Moreover, the $\mathrm{Ar} / \mathrm{Am}$ ratio reaches its maximum value within the entire profile.

Zone IV (82-34 cm; 9,260-3,303 cal. aBP) possesses the distinguishing characteristic that arboreal pollen increases to the highest value (average $40.77 \%$ ). Pinus (mean $27.91 \%$ ) and the total of other deciduous and broad-leaved arboreal pollen both reach their peak values, whereas Picea displays a trend of increase. Betula reaches a small peak value sharply at the onset of this phase and then suffers a gradual decrease with some fluctuations. Another salient characteristic is the decline of wetland pollen, such as Cyperaceae whose average percentage falls to $0.74 \%$. Sparganium only occurs at $68 \mathrm{~cm}$ and $80 \mathrm{~cm}$ with the percentage of less than $1 \%$. Besides, this zone sees a serious decline in the ratio of $\mathrm{Ar} / \mathrm{Am}$.

Zone V (34-0 cm; 3,303-0 cal. aBP) shows a large decrease in the percentage of arboreal and wetland pollen in the lower part of this phase, where Typha and Sparganium are present occasionally. However, it is noted that fern spores' percentage experiences an enormous increase to its highest value of the whole record. In the upper part of this zone, Amaranthaceae jumps sharply to the highest level of the whole profile (maximum value 61.59\%). Compared with the lower part of this zone, Betula rises and then decreases accompanied by the moderate decrease of fern spores. Typha and the submerged Potamogeton are present suddenly at the depth of $14 \mathrm{~cm}$. Ar/Am ratio decreases to 0.20 .

\section{Detrended Correspondence Analysis of Surface Pollen Spectra}

The result of DCA of the selected modern pollen types reveals that the first two axes account for $52.9 \%$ of the total variance, with eigenvalues of 0.393 and 0.078 , respectively. There is a significant relationship between Amaranthaceae and Artemisia and Axis 1. Pollen of moisture-favoring taxa (Picea and Pinus) has higher scores on Axis 2 (Fig. 5). Therefore, it is evident that humidity was the primary environmental factor controlling pollen data in this area.

Fig. 6 illustrates that despite some overlap occurs between them, surface samples collected from Ebinur Lake can be roughly divided into two vegetation zones except No. 4. Each vegetation zone corresponds to different indicative pollen obviously. For instance, Artemisia and Compositae pollen consist with the results of modern vegetation investigation in Zone I where Karelinia caspia (Compositae) is abundant; in zone II, Betula and Cyperaceae pollen match with the fact that plenty of intrazonal vegetation such as Betula microphylla, Carex arcatica and Scirpus Validus (Cyperaceae) grow here. DCA ordination result reveals that surface pollen spectra correspond with modern vegetation well, providing reference for the interpretation of paleovegetation and paleoclimate.

\section{Discussions}

\section{Paleoclimate Interpretation}

During the interval between $16,450 \mathrm{cal}$. aBP and 13,970 cal. aBP (consisting of 140-120 cm of sediment accumulation), the climate was relatively dry, as can be inferred from the following evidence. The total proportion of Pinus and Betula pollen, which tend to live in a relatively dry environment, was high, especially for Betula (which reached a peak of $12.87 \%$ ). In contrast, Picea pollen (indicating a relatively cold climate) occupied an extremely low proportion during this phase. The Ar/Am ratio was low with the exception of a small peak value. In summary, the above mentioned multi-environmental proxy analyses for this period suggest a relatively dry climate condition. This result is supported by the record of stable isotope from the lake sediments over the last 20,000 years during 16,800-11,500 aBP (Li et al., 1993). Additionally, similar results were also obtained from a synthetical study on the profile of the ZK00A core from the Bailikun Lake in the eastern Tianshan Mountains for the period ranging from 15,829 to 14,360 aBP (Han and Yuan, 1990).

From 13,970 to $12,230 \mathrm{cal}$. aBP, the climate in the study area abruptly 
changed to relatively humid conditions in this area. The dramatic decrease in the Pinus and Betula pollen (which prefer relatively dry climate) together with the slight increase in the Picea pollen (which favours relatively cold and wet conditions) reflected a considerable drop in the regional temperature during this period coinciding with the Younger Dryas abrupt climatic change event (Fairbanks, 1989; Li et al., 2011). At the same time, the distinguishing feature of this period was the increase in ferns and the presence of significant amount of aquatic pollen (e.g., Sparganium, Typha and Potamogeton) and freshwater algae (mainly composed of Concentricystes Rssignal), which indicated that humidity conditions in the studied area had effectively improved. Our results supported those of Wang et al. (2013), who reported that during 13,870-7,430 cal. aBP, the wetland pollen types including Sparganium, Potamogeton and Poaceae-S type noticeably occurred at the Ebinur Lake, indicating the existence of wetlands. Moreover, similar evidence of cold and wet climatic conditions during this period was also obtained in Lop Nur, Southeast Xinjiang (Yang et al., 2013).

Between 12,230 cal. aBP and 9,260 cal. aBP, the climate humidity rose again, which could be demonstrated by the sudden increase in arboreal pollen (Pinus and Betula), by a higher percentage of wetland pollen, and by the occurrence of Concentricystes Rssignal. Ar/Am ratios significantly increased to their peaks during this period. Surprisingly, the percentage of Picea pollen showed a clear growth trend, which was most likely due to the fact that the amount of pollen transported from the surrounding mountains by the stream currents increased with the climatic improvement and the expansion of the wetlands. Wu et al. (2005) and Jiang et al. (2003) achieved similar results of higher humidity during 11,460-10,600 cal. aBP by performing multi-environmental proxy analyses in the western Ebinur Lake. Another pollen record from the Manas Lake revealed warmer and wetter climatic conditions, leading to the recovery of the lake at about 12,000 cal. aBP (Rhodes et al., 1996). Coincidentally, this similar event occurred in Barkol Lake in Xinjiang (Han and Qu, 1992). Furthermore, our results support those of Zhao et al. (2014), who demonstrated that effective humidity was increased in the Ulungur Lake during that period.

A relatively dry climate was clearly evidenced for the period from 9,260 to 3,303 cal. aBP, with a sharp decrease in the percentage of wetland pollen and an appreciable rise in arboreal pollen, especially for deciduous and broad-leaved trees (mostly composed of Juglans, Quercus, Ulmus and Populus), which were at their all-time peak. It is worth noting that the percentage of arboreal pollen suddenly increased at the onset of that period, coinciding with the event with increasing temperature around 9,500 cal. aBP shown in the pollen record of Sayram Lake, northern Xinjiang (Jiang et al., 2013). Moreover, high-resolution multi-environmental proxy research in Qinghai Lake since Late Glacial also support this dramatic fluctuation during the early Holocene (Shen et al., 2004).

After this period, the Ebinur birch wetland maintained a relatively humid climate, corresponding well with the Holocene Megathermal (Colman et al., 2007). Especially during 8,000-5,000 cal. aBP, arboreal pollen maintained its highest level and Ranunculaceae occurred frequently in the study area at the expense of xerophytic Compositae, indicating that the climatic conditions were quite suitable in this phase. Our results were consistent with those in other lakes in northern Xinjiang including the Manas Lake (Lin et al., 1996), Ulungur Lake (Jiang et al., 2006), and Barkol Lake (Wang et al., 2014).
At about 5,000 cal. aBP, a short-lived cooling event was inferred from the almost-complete disappearance of the Betula pollen and the decrease to a relatively low level in Ranunculaceae. This observation corresponded to evidence from carbon isotope in Ebinur Lake (Li et al., 1993) and pollen record from the Barkol Lake (Han and Yuan, 1990).

After 3,303 cal. aBP, the climate became drier, leading to a significant increase in the percentages of Compositae and a clear decrease in trees, especially Pinus. However, both Cyperaceae and submerged Potamogeton reached their maximum percentage for this period during 1,000-600 cal. aBP, indicating a period of increased humidity. This relatively wetting climatic event was also reflected in the studies of Yan et al. (2003) and Miao et al. (2003), which inferred the occurrence of a high-water-level period in Ebinur Lake. Moreover, a multi-proxy paleoclimate, which was inferred from three Holocene sediment profiles from northern Xinjiang located in different elevations and vegetation zones, demonstrated that the climate was relatively humid during the MWP, spanning from the middle of the Tang Dynasty to the middle of the Yuan Dynasty (Zhang et al., 2009). Consequently, our study in Ebinur birch wetland provided compelling evidence of humidity conditions during the MWP.

From 600 cal. aBP onwards, the pollen assemblages were characterized by the significant increase in Amaranthaceae and sand particles, suggesting a distinct shift towards a drier climate and a deterioration of the environment, which was also reported in other lakes in northern Xinjiang by performing high-resolution multi-environmental-proxy analyses (Miao et al., 2003; Yan et al., 2003; Tao et al., 2010). In addition to the above-mentioned natural factors, intensified human activities over the last 600 years may also account for the substantial rise in Amaranthaceae (Zhang et al., 2009, 2010; Zhang, et al., 2015).

\section{Betula Pollen in Ebinur Birch Wetland}

The relatively high contents of the Betula pollen recorded in the Caotan wetland profiles in northern Xinjiang was regarded as convincing evidence that birch forests grew in wetlands at low elevations during historic periods (Zhang et al., 2013), broadly similar to the modern vegetational landscape in the Ebinur birch wetland. However, the extremely small amount of birch trees left in the Caotan wetland is highly endangered. Similarly, the endangered species Ebinur birch only survives in the Birch Conservation station of the Ebinur Lake Wetland Nature Reserve, with only 328 remaining birch trees (Betula microphylla) (Chen et al., 2006; Zhang et al., 2013). Therefore, it is critical to explore the evolutionary history of Betula in this area and provide valuable information for the protection of this endangered species.

Three high peaks of Betula pollen in the Ebinur birch wetland occurred in Zone I, the early stage of Zone IV and the late stage of Zone $\mathrm{V}$, respectively. The climatic conditions with increasing temperature followed by the end of the Last Glacial Maximum in Zone I should account for the first peak of Betula pollen, from which we inferred that a moderate stretch of birch forest could grow well in places with enough moisture. This similar event was also found in records from samples of NGRIP $\delta^{18} \mathrm{O}$ record (Seierstad et al., 2004) (Fig. 7). During the period from 13,970 to $12,230 \mathrm{cal}$. aBP, the climate in the Ebinur birch wetland became relatively cold and humid under the effect of the Younger Dryas cold event, leading to a sharp decline in the birch 
(a)

NGRIP $\delta^{18} \mathrm{O}$ record

(modified from

Seierstad et al., 2014)

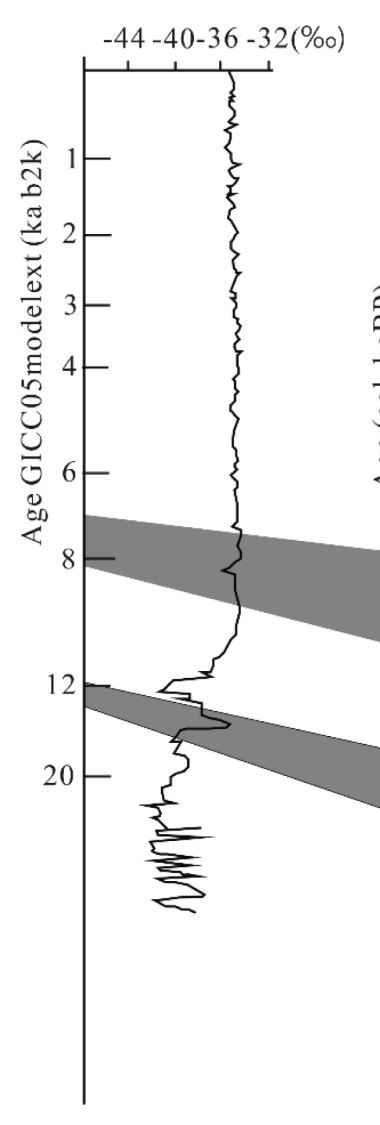

(b)

Temperature recorded

in the Owasco Lake

(modified from $\begin{array}{ll}\text { (modified from } & \text { (modified from } \\ \text { Mullins and Halfman, 2001) } & \text { Yang et al., 2002) }\end{array}$ (c)

Temperature variation in "complete" China (d)

Three high peaks of Betula pollen in the Ebinur birch wetland
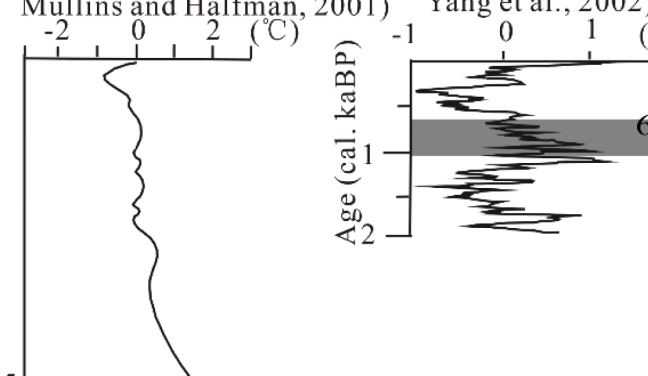
$\left.{ }^{\circ} \mathrm{C}\right)$

$\operatorname{Depth}(\mathrm{cm})$ 


\section{Conclusion}

Fossil pollen data from the sediment profile of the Ebinur birch wetland show significant climate changes during the last 16,450 years. Before 13,970 cal. aBP, the climate was relatively dry and then suddenly became wetter until 12,230 cal. aBP. This recorded decrease in temperature coincided well with the Younger Dryas in Europe. From 12,230 to 9,260 cal. aBP, regional climate was dominated by increasing humidity conditions. Subsequently, a significant increase in arboreal pollen and the disappearance of wetland pollen demonstrated a relatively and dry climate during 9,260-3,303 cal. aBP. Since 3,303 cal. aBP, the climate has dried further, except for the short-lived amelioration of moisture during the MWP.

Three peaks in the levels of the Betula pollen have appeared since 16,450 cal. aBP, all of which accompanied by the improvement of climatic conditions. The earlier peak occurred behind the Last Glacial Maximum with increasing temperature, the second peak occurred at the beginning of early Holocene, and the latter peak falls within the MWP when the climate was relatively humid in the Xinjiang region of China. The significantly increase of Amaranthaceae content and the rapid reduce of $\mathrm{Ar} / \mathrm{Am}$ ratio indicated that the decrease of birch pollen content was related to the drying of climate and the intensification of human activities over the past 600 years.

There are still some deficiencies in this study, which need to be further strengthened in the future. However, there is no doubt that these fossil pollen data can provide valuable reference for paleoclimate and paleovegetation interpretation in this area, and it is helpful to reveal the influence of climate change and human activities on local vegetation evolution in different historical periods. It can also provide scientific basis for wetland ecosystem restoration and ecological civilization construction in Xinjiang of China.

\section{Acknowledgements}

The work was supported by the National Natural Science Foundation of China (Grant No. 41971121 and 41572331), the Strategic Priority Research Program of the Chinese Academy of Sciences (Grant No. XDA19050103), and the Scientific Research Foundation for the Returned Overseas Chinese Scholars, State Education Ministry.

\section{References}

Chen, S.J., Hou, P., and Li, W.H., 2006, Comprehensive scientific investigation of Ebinur Lake wetland nature reserve in Xinjiang. Xinjiang Science and Technology Press, Urumuqi.

Colman, S.M., Yu, S.Y., An, Z.S., Shen, J., and Henderson, A.C.G., 2007, Late Cenozoic climate changes in China's western interior: a review of research on Lake Qinghai and comparison with other records. Quaternary Science Reviews, v. 26, pp. 2281-2300, doi.org/10.1016/j.quascirev.2007.05.002

Fairbanks, R.G., 1989, A 17,000-year glacio-eustatic sea-level record influence of glacial melting rates on the Younger Dryas event and deep-ocean circulation. Nature, v. 342, pp. 637-642, doi.org/10.1038/ $342637 \mathrm{a} 0$

Feng, X.H., Yan, S., Ni, J., Kong, Z.C., and Yang, Z.J., 2006, Environmental changes and lake level fluctuation recorded by lakes on the plain in northern Xinjiang during the late Holocene, Chinese Science Bulletin, v. 51, pp. 60-67, doi.org/10.1007/s11434-006-8208-x

Grimm, E.C., 1990, Tilia and Tilia Graph: PC spreadsheet and graphics software for pollen data. INQUA commission for the study of the Holocene: working group on data-handling methods. Newsletter, v. 4, pp. $5-7$.

Guiot, J., 2012, A robust spatial reconstruction of April to September temperature in Europe: Comparisons between the medieval period and the recent warming with a focus on extreme values. Global and Planetary Change, v. 84-85, pp. 14-22. doi.org/10.1016/j.gloplacha.2011.07.007

Han, S.T., and Qu, Z., 1992, The characteristics of inland-type climate during the Holocene in Balikun Lake, northern Xinjiang. Science China B, v. 11, pp. 1201-1209.

Han, S.T., and Yuan, Y.J., 1990, The sequence of paleoclimatic variation of Balikun Lake of Xinjiang in the past 35000 years. Acta Geographica Sinica, v. 45, pp. 350-362.

Hughes, M.K., and Diaz, H.F., 1994, Was there a Medieval Warm Period, and if so, where and when. Climatic Change, v. 26, pp. 109-142.

Jiang, J.M., and Wu, J.L., 2003, Lake Sediment Records of the Holocene Environmental Evolution in North Xinjiang. Geological Journal of China Universities, v. 9, pp. 30-37.

Jiang, Q.F., Liu, X.Q., and Shen, J., 2006, Grain-size Characteristics of Wulugu Lake Sedmients and Its Palaeoclmiate and Palaeoenvironment Implication. Acta Sedimentologica Sinica, v. 24, pp. 877-882, doi.org/10.1007/s11442-006-0415-5

Jiang, Q.F., Ji, J.F., Shen, J., Matsumoto, R., Tong, G.B., Qian, P., Ren, X.M., and Yan, D.Z., 2013, Holocene vegetational and climatic variation in westerly-dominated areas of Central Asia inferred from the Sayram Lake in northern Xinjiang, China. Science China-Earth Sciences, v. 56, pp. 339-353.

Ledru, M.P., Jomelli, V., Bremond, L., Ortuño, T., Cruz, P., Bentaleb I., Sylvestre, F., Kuentz, A., Beck, S., Martin, C., Paillès, C., and Subitani, S., 2013, Evidence of moist niches in the Bolivian Andes during the mid-Holocene arid period. Holocene, v. 23, pp. 1547-1559, doi.org/ $10.1177 / 0959683613496288$

Li, G.S., 1993, Study of $\delta^{13} \mathrm{C}$ records and climatic events in Aibi Lake since Deglaciation. Chinese Science Bulletin, v. 38, pp. 2069-2072.

Li, X.Q., Zhao, K.L., Dodson, J., and Zhou, X.Y., 2011, Moisture dynamics in central Asia for the last 15 kyr: new evidence from Yili Valley, Xinjiang, NW China. Quaternary Science Review, v. 30, pp. 3457-3466, doi.org/ 10.1016/j.quascirev.2011.09.010

Lin, R.F., Wei, K.Q., Cheng, Z.Y., Wang, Z.X., Gasse, F., Fontes, J.Ch., Gibert, E., and Tucholka, P., 1996, A palaeoclimatic study on lacustrine cores from Manas Lake, Xinjiang, western China. Geochimica, v. 25, pp. 63-72.

Ma, L., Wu, J.L., Yu, H., Zeng, H.A., and Jilili, A., 2011, The Medieval Warm Period and the Little Ice Age from a sediment record of Lake Ebinur, northwest China. Boreas, v. 40, pp. 518-524, doi.org/10.1111/ j.1502-3885.2010.00200.x

Miao, Z., Mu, G.J., Yan, S., and Xie, H.Q., 2003, Environmental Evolution of Aiby Lake Indicated by Ash core Sediment's Information. Arid Land Geography, v. 26, pp. 367-371.

Mullins, H.T., and Halfman, J.D., 2001, High-resoultion seismic reflection evidence for middle Holocene environmental change, Owasco Lake, New York. Quaternary Research, v. 55, pp. 322-331, doi.org/10.1006/ qres. 2001.2232

Rhodes, T.E., Gasse, F., Lin, R.F., Fontes J.C., Wei, K.Q., Bertrand, P., Gibert, E., Mélières, F., Tucholka, P., Wang, Z.X., and Cheng, Z.Y., 1996, A late Pleistocene-Holocene lacustrine record from Lake Manas, Zunggar (northern Xinjiang, western China), Palaeogeography Palaeoclimatology Palaeoecology, v., 120, pp. 105-121.

Seierstad, I.K., Abbott, P.M., Bigler, M., Blunier, T., Bourne, A.J., Brook, E., Buchardt, S. L., Buizert, C., Clausen, H.B., Cook, E., Dahl-Jensen, D., Davies, S.M., Guillevic, M., Johnsen, S., Pedersen, D.S., Popp, T.J., Rasmussen, S.O., Severinghaus, J.P., Svensson, A., and Vinther, B.M., 
2014, Consistently dated records from the Greenland GRIP, GISP2 and NGRIP ice cores fort he past 104 ka reveal regional millennial-scale $\delta^{18} \mathrm{O}$ gradients with possible Heinrich event imprint, Quaternary Science Reviews, v. 106, pp. 29-46, doi.org/10.1016/j.quascirev.2014.10.032

Shen, J., Liu, X.Q., Matsumoto, R., Wang, S.M., and Yang, X.D., 2004, A high-resolution climatic change since the Late Glacial age inferred from multiproxy of sediments in Qinghai Lake. Science China Earth Science, v. 34, pp. 742-751, doi.org/10.1360/03yd0148

Tao, S.C., An, C.B., Chen, F.H., Tang, L.Y., Wang, Z.L., Lv, Y.B., Li, Z.F., Zheng, T.M., and Zhao, J.J., 2010, Pollen-inferred vegetation and environmental changes since $16.7 \mathrm{kaBP}$ at Balikun Lake, Xinjiang. Chinese Science Bulletin, v. 55, pp. 2449-2457, doi.org/10.1007/s11434010-3174-8

Viau, A.E., Ladd, M., and Gajewski, K., 2012, The climate of North America during the past 2000 years reconstructed from pollen data. Global and Planetary Change, v. 84-85, pp. 75-83, doi.org/10.1016/ j.gloplacha.2011.09.010

Wang, H.Y., Yue, L.P., Li, J.X., and Yang, L.R., 2014, Changing of the Lake Area and Records of Climate and Environment of Barkol Lake During Holocene. Acta Sedimentologica Sinica, v. 32, pp. 93-100.

Wang, W., Feng, Z.D., Ran, M., and Zhang, C.J., 2013, Holocene climate and vegetation changes inferred from pollen records of Lake Aibi, northern Xinjiang, China: A potential contribution to understanding of Holocene climate pattern in East-central Asia. Quaternary International, v. 311, pp. 54-62, doi.org/10.1016/j.quaint.2013.07.034

Wu, J.L., Shen, J., and Wang, S.M., 2005, Characteristics of an early Holocene climate and environment from lake sediments in Ebinur region, NW China. Science in China series D-Earth Sciences, v. 48, pp. 258265, doi.org/10.1360/02yd0298

Yan, S., Mu, G.J., Kunihiko, E., Handa, N., Uchida, M., and Harada, N., 2003, Environmental Evolution Information from Aiby Lake since the Last 2500a. Arid Land Geography, v. 26, pp. 227-231.

Yang, B., Braeuning, A., Johnson, K.R., and Shi, Y.F., 2002, General characteristics of temperature variation in China during the last two millennia. Geophysical Research Letters, v. 29, pp. 1-4, doi.org/10.1029/2001GL014485

Yang, D., Peng, Z.C., and Luo C., 2013, High-resolution pollen sequence

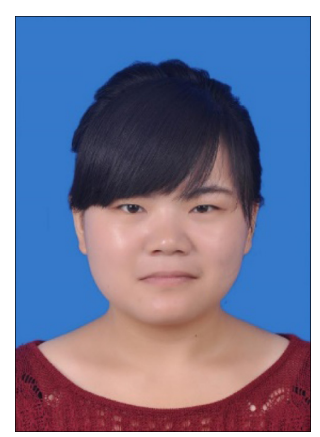

Li Wang is now a doctoral student at School of Geography and Sustainable Development, University of St Andrews. She has been working on Holocene vegetation change and environmental change in North Xinjiang of China since 2016.

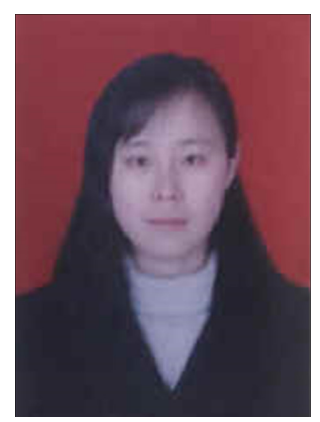

Yun Zhang is associate professor at State Key Laboratory of Vegetation and Environmental Change, Institute of Botany, Chinese Academy of Science, China. She has been working on Quaternary Palynology and Paleoecology since 1999. Her research interests are mainly focused on Holocene vegetation change and wetland change in Xinjiang of China. from Lop Nur, Xinjiang, China: Implications on environmental changes during the late Pleistocene to the early Holocene. Review of Palaeobotany and Palynology, v. 192, pp. 32-411, doi.org/10.1016/j.revpalbo.2012.12.002

Zhang, D.L., Chen, X., Li, Y., and Zhang, S.R, 2020, Holocene vegetation dynamics and associated climate changes in the Altai Mountains of the Arid Central Asia. Palaeogeography Palaeoclimatology Palaeoecology, v. 550, doi.org/10.1016/j.palaeo.2020.109744

Zhang, H., Zhang, Y., Kong, Z.C., Yang,Z.J., Li, Y.M., and Tarasov, P., 2015, Late Holocene climate change and anthropogenic activities in north Xinjiang: Evidence from a peatland archive, the Caotanhu wetland. Holocene, v. 25, pp. 323-332, doi.org/10.1177/0959683614558646

Zhang, Y., Kong, Z.C., Yan, S., Yang, Z.J., and Ni, J., 2009, "Medieval Warm Period" on the northern slope of central Tianshan Mountains, Xinjiang, NW China. Geophysical Research Letters, v. 36, L11702, doi.org/10.1029/2009GL037375

Zhang, Y., Kong, Z.C., Wang, G.H., and Ni., J, 2010. Anthropogenic and climatic influence on surface pollen assemblages along a precipitation gradient in north-eastern China. Global Ecology and Biogeography, v. 19, pp. 621-631, doi.org/10.1111/j.1466-8238.2010.00534.x

Zhang, Y., Kong, Z.C, and Zhang, H., 2013, Multivariate Analysis of Modern and Fossil pollen Data from Central Tianshan Mountains, Xinjiang, NW China. Climatic Change, v. 120, pp. 945-957, doi.org/10.1007/s10584013-0838-9

Zhang, Y., Kong, Z.C., Yang, Z.J., Wang, L., and Duan, X.H., 2017, Surface Pollen Distribution from Alpine Vegetation in Eastern Tibet, China. Scientific Reports, v. 7, pp. 586, doi.org/10.1038/s41598-017-00625-7

Zhang, Y., and Kong, Z.C., 2019, Changes in wetland salinity, human activity and wetland vegetation abundances over the past 900 years. Global and Planetary Change, v. 182, 103000, doi.org/10.1016/j.gloplacha.2019.103000

Zhao, Y.T., An, C.B., and Chen, Y.F., 2014, A high-resolution climatic change since the Late Glacial Age inferred from multi-proxy of sediments in Ulungur Lake. Arid Land Geography, v. 37, pp. 222-229, doi.org/ $10.1360 / 03 \mathrm{yd} 0148$

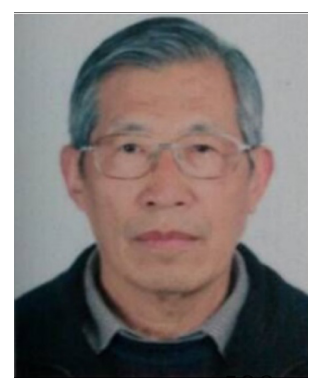

Zhaochen Kong is a Professor at State Key Laboratory of Vegetation and Environmental Change, Institute of Botany, Chinese Academy of Sciences. His research interests are mainly focused on vegetation change and climate change in China. 